\title{
SP-Sephadex Equilibrium Chromatography of Bradykinin and Related Peptides: Application to Trypsin-Treated Human Plasma ${ }^{1,2}$
}

\author{
Misako U. Sampaio, ${ }^{3}$ Marina L. Reis, ${ }^{4 *}$ Edwin Fink, ${ }^{5}$ \\ Antonio C. M. Camargo, ${ }^{6}$ and Lewis J. Greene ${ }^{7}$ \\ Biology Department, Brookhaten National Laboratory. Upton. New York 11973: and \\ Protein Chemistry Laboratory. Departments of Biochemistry and Pharmacology. \\ Facally of Medicine of Ribeiräo Preto, and *Department of Physiological \\ Sciences, Faculty of Dentistry and Pharmacy of Ribeiräo Preto. \\ University of Săo Paulo, 14.100 Ribeiráo Preto, Säo Paulo, Bra-il
}

Received February 16, 1977; accepted April 12, 1977

An analytical method is described for the separation of bradykinin. Lysbradykinin. and Met-Lys-bradykinin by equilibrium chromatography on SPSephadex $\mathrm{C}-25$ eluted in $0.02 \mathrm{M}$ Tris- $\mathrm{HCl}$ buffer, $\mathrm{pH} 8.10 .0 .12 \mathrm{M} \mathrm{NaCl}$. A second elution buffer, $0.02 \mathrm{M}$ Tris $-\mathrm{HCl}$ buffer, $\mathrm{pH} 7.70 .0 .06 \mathrm{M} \mathrm{NaCl}$. serves

1 The U. S. Government's right to retain a nonexclusive royalty-fiee license in and to copyright covering this paper is acknowledged.

"A preliminary report of part of these findings was presented at the Conference on the Chemistry and Biology of the Kallikrein-Kinin System in Health and Disease, Reston. Va.. October 1974. The abstract is given in Ref. (1).

${ }^{3}$ Visiting Biochemist at Brookhaven National Laboratory, 1970-1972. Supported by Fundação de Amparo à Pesquisa do Estado de São Paulo (FAPESP). Permanent address: Department of Biochemistry, Escola Paulista de Medicina. Rua Botucatu, 862. Caixa Postal 20.372. 04023 São Paulo. Brazil.

* Visiting Pharmacologist at Brookhaven National Laboratory. 1973. Supported by Fundação de Amparo à Pesquisa do Estado de São Paulo (FAPESP). Permanent address: Department of Physiological Sciences. Faculty of Dentistry and Pharmacy of Ribeirão Preto, University of Sáo Paulo. 14.100 Ribeirão Preto, São Paulo, Brazil.

"Visiting Biochemist at Brookhaven National Laboratory, 1972-1974. Supported by Deutsche Forschungsgemeinschaft. Permanent address: Institüt für Klinische Chemie und Klinische Biochemie der Universität München. D-9 München 2. Nussbaumstrasse 20. Germany.

- Visiting Biochemist at Brookhaven National Laboratory. 1970-1972. Supported by Fundação de Amparo à Pesquisa do Estado de São Paulo (FAPESP). Permanent address: Department of Pharmacology. Faculty of Medicine of Ribeirāo Preto. University of São Paulo. 14.100 Riheirão Preto, São Paulo. Brazil.

'To whom requests for reprints should be made. Biochemist. Biology Department. Brookhaven National Laboratory, and Visiting Professor, Department of Biochemistry. Faculty of Medicine of Ribeirão Preto. University of São Paulo. Permanent address: Department of Biochemistry, Faculty of Medicine of Ribeiräo Preto. University of São Paulo, 14.100 Ribeiräo Preto, São Paulo, Brazil. 
as a second parameter for the identification of bradykinin and also separates the hormone from plasma bradykinin-potentiating peptides. Ten to one-hundred nanomoles of each peptide can be recovered in high yields, identified by elution position. and measured by bioassay with the isolated guinea pig ileum. The identification of bradykinin as the peptide released by trypsin acting on acid-denatured plasma is documented as an illustration of the method.

The group of structurally related vasoactive polypeptides bradykinin. Arg-Pro-Pro-Gly-Phe-Ser-Pro-Phe-Arg (K-9), Lys-bradykinin (K-10), and Met-Lys-bradykinin (K-11) constitutes $1-2 \%$ of the polypeptide chain of kininogen, an inactive precursor protein present in plasma. These peptide hormones can be released by several proteolytic enzymes including trypsin, kallikrein, plasmin, acrosin, pepsin, and some snake venom proteases. Further hydrolysis by aminopeptidases can convert Lys-bradykinin and Met-Lys-bradykinin to the limit product, bradykinin. Since the three peptides have vastly different specific activities for contraction of smooth muscle, increase of vascular permeability, and depression of systemic blood pressure, the combination of the specificity of the releasing enzymes, the subsequent conversion by aminopeptidases, and the different rates of inactivation provides a mechanism for the modulation of the activity of these hormones in circulation and in tissue [cf. Refs. (2-4) for recent reviews].

The analytical problems associated with desalting, identifying and measuring nanomole quantities of each peptide, have limited the attempts to determine levels of each of these hormones in various physiological and pathological conditions. These problems have also hindered studies of the specificity and the kinetics of the enzymes which hydrolyze these peptide and protein substrates.

In the accompanying paper (5), we showed that AG $11 \mathrm{~A} 8$ ion-retardation resin effectively separates nanomole quantities of kinins from salts and buffer ions present in ethanol extracts of trypsin-treated plasma prepared under the conditions described by Diniz and Carvalho (6) for the determination of human plasma kininogen. In this paper, we describe the properties of an equilibrium chromatography system using SPSephadex C-25 for the separation and identification of K-9, K-10, and $\mathrm{K}-11$. The AG $11 \mathrm{~A} 8$ and SP-Sephadex C-25 systems taken together provide an analytical method for the identification of kinins at the nanomole level, which is illustrated by application to the identification of the kinins released by trypsin acting on human plasma.

\section{MATERIALS}

Valves, timers, and fittings were purchased from M.E.R. Chromatographic, Mountain View, Calif., and sample holders were manufactured by Aquebogue Machine Shop, Aquebogue, N. Y. The microbore column 
and fittings were purchased from Chromatronix, Inc.. Berkeley, Calif. Polyethlene glycol was obtained from Fisher Scientific Co., Pittsburgh, Pa. SP-Sephadex C-25 is a product of Pharmacia Fine Chemicals, Piscataway, N. J. $\alpha$-Chymotrypsin (CDI) and carboxypeptidase B (COBDFP) were products of Worthington Biochemicals, Freehold, N. J. All glassware and columns were treated with Siliclad (Clay Adams, Parsippany, N. J.). All other chemicals were reagent grade or have been described in Refs. $(5,7)$.

\section{METHODS}

Apparatus. Sample application, column development, resin regeneration, and resin equilibration are carried out automatically with an apparatus assembled from commercially available parts. Reservoirs containing buffer or $0.1 \mathrm{~N} \mathrm{NaOH}$ are connected with $1 / 8$-in.-o.d. $\times 1 / 16^{\text {-in.-i.d. }}$ Teflon or polyethylene tubing, through a motor-driven three-inlet valve (M.E.R. No. MV-4), to a Milton-Roy minipump (No. 196-31). The buffer is introduced to inlets 1 and 3, and inlet 2 is used for $0.1 \mathrm{~N} \mathrm{NaOH}$. The motor valve is controlled by a dual timer (M.E.R. No. T-300) to provide buffer, $0.1 \mathrm{~N} \mathrm{NaOH}$, followed by the same buffer to the pump for preselected periods of time. A separate timer (Dimco-Gray Company, Model No. 176, $15 \mathrm{hr}$ ) and relay are used to control the total operating time of the pump. The outlet of the pump is fitted with a tee connector (M.E.R. No. 4040) to accomodate a pressure gauge (M.E.R. No. 6060). A line filter assembly (M.E.R. No. TF-12) containing porous Teflon disks (M.E.R. No. 313, $50 \mu \mathrm{m}$ ) is connected to the second port of the tee to provide back pressure for the pump and to filter buffer solutions. A sample tube (Kel-F, Aquebogue Machine Shop) is located between the line filter and the $0.28 \times 50-\mathrm{cm}$ column (Chromatronix No. MB-3-500). The stainless steel bed-support disk supplied with the column was replaced by a porous Teflon support. The sample tube $(1-, 3-$, or $4.5-\mathrm{ml}$ capacity) is closed with a semiball connector held in place by two clamps [cf. Fig. 1 in Ref. (8)]. Teflon tubing, $1 / 16$ in. o.d. $\times 1 / 32$ in. o.d., is used for all lines after the pump and connections are made with fittings obtained from Chromatronix or the equivalent. Alternate apparatus may be used to operate the columns; however, the sample tube system (8) line with the column provides convenient and reproducible addition of measured volumes of large samples to the column.

Column preparation. SP-Sephadex is equilibrated by suspending the resin in $10 \mathrm{vol}$ of buffer, correcting the $\mathrm{pH}$, and resuspending the slurry (after decantation) three times in 5 vol of buffer. The suspension is gently stirred with a magnetic stirring bar. Vigorous agitation should be avoided, for it produces fine particles. The suspension is degassed on a water pump in order to prevent bubble formation while pouring the column. The column is filled halfway with buffer, and the flow is stopped 
by raising the outlet tube above the liquid level in the column. A dilute suspension of the resin is introduced into the column below the liquid level from a beaker through a polyethylene tube by siphon action. The slurry must be dilute to prevent clumping of the resin and to permit small air bubbles to rise to the top of the column. After $2-3 \mathrm{~cm}$ of column bed has been formed, flow is started from the bottom of the column by lowering the outlet tube. The column must be completely filled with resin to prevent formation of a buffer space which would dilute the sample during application. The resin is taken through one complete cycle (sample buffer application, development, regeneration, and equilibration) to stabilize the resin bed. It is usually necessary to add $1-2 \mathrm{~cm}$ of additional resin to the bed. The operating back pressure of the system was usually less than 5 psi, due primarily to the porous Teflon disks in the buffer filters. Occasionally, back pressure $>50$ psi developed during sample application, due to clogging of the bed support disk at the bottom of the column. The disk must be replaced, and the column must be repoured.

Buffers. The two buffer systems which proved best for the applications described here were: (A) $0.02 \mathrm{M}$ Tris- $\mathrm{HCl}$ buffer, $\mathrm{pH} 8.10,0.12 \mathrm{M}$ $\mathrm{NaCl}$, and (B) $0.02 \mathrm{M}$ Tris- $\mathrm{HCl}$ buffer, $\mathrm{pH} 7.70,0.06 \mathrm{M} \mathrm{NaCl}$. Because the elution positions of the peptides are extremely sensitive to $\mathrm{NaCl}$ concentration and $\mathrm{pH}$, the buffers were prepared in 2-liter batches and were stored at $4^{\circ} \mathrm{C}$ to assure sufficient buffer for 10-20 columns. The conductivity and $\mathrm{pH}$ of a fresh buffer were compared directly with the buffer previously used, and the fresh buffer was discarded if not identical. Buffer $\mathrm{A}, \mathrm{pH} 8.10$, provided good resolutions of kinins 9, 10, and 11 (cf. Fig. 1), but the leading edge of the K-9 profile contained small amounts of bradykinin-potentiating peptides produced by the action of trypsin on plasma proteins $(9.10)$. Buffer $\mathrm{B}, \mathrm{pH} 7.70$, provided complete separation of K-9 from bradykinin-potentiating peptides liberated from plasma proteins by trypsin (cf. Fig. 3), but was not useful for the determination of kinins 10 and 11 because they were greatly retarded. Experimental samples were analyzed with both buffer systems.

Column operation. The sample is diluted in appropriate buffers to give a final concentration of $0.05 \mathrm{M}$ MOPS- $\mathrm{HCl}$ buffer, ${ }^{8} \mathrm{pH} \mathrm{7.0,} \mathrm{and} 15 \%(\mathrm{v} / \mathrm{v})$ polyethylene glycol 400. PEG is added for "layering" during sample application (8). A measured aliquot of the sample $(0.5-4.0 \mathrm{ml})$ is transferred to the sample tube with a micropipet, and the volume remaining is completed with $0.05 \mathrm{M}$ MOPS- $\mathrm{HCl}$ buffer, $\mathrm{pH} \mathrm{7.0,} \mathrm{which} \mathrm{does} \mathrm{not}$ contain PEG. The sample buffer and column operating conditions are the same for $\mathrm{pH} 7.70$ and 8.10 developing buffers. The column is operated

\footnotetext{
"Abbreviations used: MOPS, morpholino-propanesulfonic acid: PEG, polyethylene glycol.
} 
under equilibrium conditions after sample application at $25^{\circ} \mathrm{C}$ at $6 \mathrm{ml} / \mathrm{hr}$, and $1-\mathrm{ml}$ fractions are collected. The column is regenerated at the end of the run with $3 \mathrm{ml}$ of $0.1 \mathrm{~N} \mathrm{NaOH}$ and is equilibrated with $60 \mathrm{ml}$ of developing buffer.

The void volume $\left(V_{0}\right)$ of the SP-Sephadex column was determined with $15 \mu \mathrm{mol}$ of cysteic acid and $15 \mu \mathrm{mol}$ of sodium phosphate in 4.0 $\mathrm{ml}$ of $0.05 \mathrm{M}$ MOPS $-\mathrm{HCl}$ buffer, $\mathrm{pH} 7.0$, containing $15 \%(\mathrm{v} / \mathrm{v})$ polyethylene glycol. Fractions of $0.2 \mathrm{ml}$ were collected. Cysteic acid and phosphate were detected in $0.1-\mathrm{ml}$ aliquots of the effluent by reaction with ninhydrin (11) and by mixture with an equal volume of a saturated solution of barium chloride, respectively.

Isolated guinea pig ileum assay for kinins. Kinin activity was determined by measuring the isotonic contraction of isolated guinea pig ileum suspended at $37^{\circ} \mathrm{C}$ in aerated Tyrode solution containing 3.5 $\times 10^{-7} \mathrm{M}$ atropine and $1.7 \times 10^{-6} \mathrm{M}$ diphenylhydramine. The measurement of $\mathrm{K}-9, \mathrm{~K}-10$, and $\mathrm{K}-11$ was done by direct matching of the extent of contraction with standard solutions of the appropriate peptide. The concentration of peptide in standard solutions was determined by amino acid analysis after acid hydrolysis (5). Aliquots of up to $0.5 \mathrm{ml}$ of column effluent, containing $0.02 \mathrm{M}$ Tris $-\mathrm{HCl}$ buffer and varying amounts of $\mathrm{NaCl}$ up to $0.15 \mathrm{M}$ at $\mathrm{pH} 7.70$ or 8.10 , can be assayed directly on the isolated guinea pig ileum ( $10-\mathrm{ml}$ incubation volume) without interfering with the assay. The potentiating peptides were located in the column effluent by a qualitative assay similar to the quantitative assay described by Ferreira et al. (12). Conversion of K-11 to K-9 was carried out in the $\mathrm{pH} 8.1$ column effluent by the addition of trypsin $(5 \mu \mathrm{g} / \mathrm{ml})$. Control experiments were performed in parallel with synthetic K-11 at the same concentration.

Enzymatic inactivation of bradykinin. The column effluent corresponding to the elution position of bradykinin was pooled and treated either with $\alpha$-chymotrypsin $(10 \mu \mathrm{g} / \mathrm{ml})$ or carboxypeptidase $\mathrm{B}(6.0 \mu \mathrm{g} / \mathrm{ml})$ at $37^{\circ} \mathrm{C}$. The rate of inactivation was compared with that of synthetic bradykinin at the same concentration in the same buffer. The isolated guinea pig ileum bioassay was used to measure the residual bradykinin activity.

Determination of the limit of detection for bradykinin, Lys-bradykinin, and Met-Lys-bradykinin. The peptides $(0.2-10 \mathrm{nmol}$ in a 4-ml sample buffer) were chromatographed individually on SP-Sephadex at $\mathrm{pH} 8.1$. The effluent was monitored by bioassay using up to $0.5 \mathrm{ml}$ of effluent/assay. Variability in the sensitivity of the ileum from different animals made it necessary to select, for these experiments, tissue which would respond to $0.02 \mathrm{nmol}$ of bradykinin with a full-scale deflection of the chymograph.

Release of kinin activity by trypsin treatment of acid-denatured human plasma. The experimental conditions for the release of kinin activity and desalting on $A G 11 \mathrm{~A} 8$ resin are given in Ref. (5). 


\section{RESULTS}

Equilibrium Chromatography of $K-9, K-10$, and $K-11$ on SP-Sephadex C-25

The experimental conditions for equilibrium chromatography were determined, in a series of test tube experiments, to measure the distribution coefficient of the peptides between the liquid and resin phases as a function of $\mathrm{pH}$ and ionic strength (13) and were then refined in column experiments. The concentration of Tris- $\mathrm{HCl}$ buffer was arbitrarily set at $0.02 \mathrm{M}$ to permit the use of aliquots containing as much as $0.5 \mathrm{ml}$ of column effluent for bioassay of kinins with the isolated guinea pig ileum. The void volume of the column $\left(V_{0}\right)$, determined with cysteic acid and phosphate, was $1.2 \mathrm{ml}$ of both the $\mathrm{pH} 7.70$ and 8.10 buffers. The total volume of the column $\left(V_{T}\right)$, determined volumetrically, was $3.0 \mathrm{ml}$.

The elution diagram given in Fig. 1, top, was obtained with $0.02 \mathrm{M}$ Tris $-\mathrm{HCl}$ buffer, $\mathrm{pH} 8.10$, containing $0.12 \mathrm{M} \mathrm{NaCl}$. The transmission at 206 $\mathrm{nm}$ is given in Fig. 2B. Bradykinin, Met-Lys-bradykinin, and Lys-bradykinin are eluted at 20,38 , and $56 \mathrm{ml}$. The recovery of biological activity was generally $70-90 \%$ for 10 - to 100 -nmol samples. The elution volume between the peptides is sufficient to permit quantitation without inter-

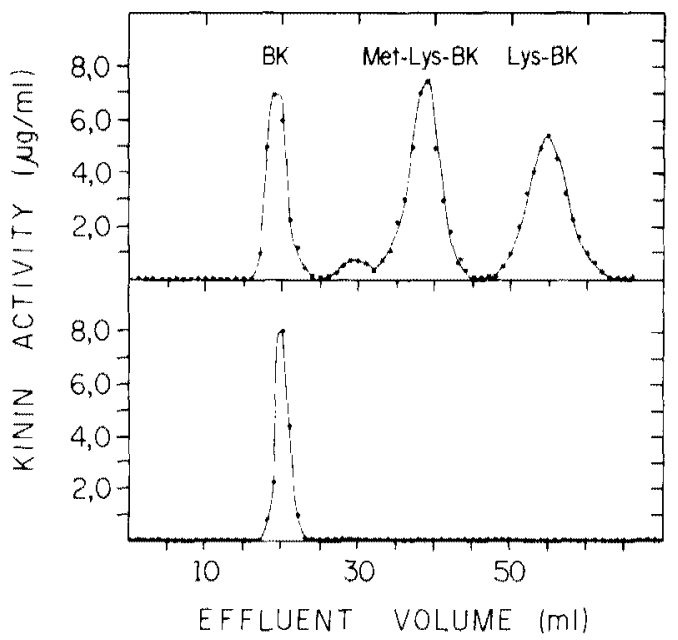

FIG. I. Equilibrium chromatography of synthetic bradykinin. Lys-bradykinin. and Met-Lys-bradykinin (top) and the kinin released by trypsin acting on acid-denatured human plasma (bottom) on SP-Sephadex $\mathrm{C}-25$ at $\mathrm{pH} 8.10$. The column, $0.3 \times 50 \mathrm{~cm}$. was developed with $0.02 \mathrm{M}$ Tris $-\mathrm{HCl}$ buffer, $\mathrm{pH} 8.10,0.12 \mathrm{M} \mathrm{NaCl}$ at $6 \mathrm{ml} / \mathrm{hr}, 25^{\circ} \mathrm{C}$. Top: The sample contained 25. 40, and $90 \mu \mathrm{g}$ of bradykinin. Lys-bradykinin. and MetLys-bradykinin, respectively. Bottom: The sample was derived from $6 \mathrm{ml}$ of plasma and had been desalted on $A G$ IIA8 resin. It contained $24 \mu \mathrm{g}$ of bradykinin equivalents. Biological activity was determined with the isolated guinea pig ileum assay. 


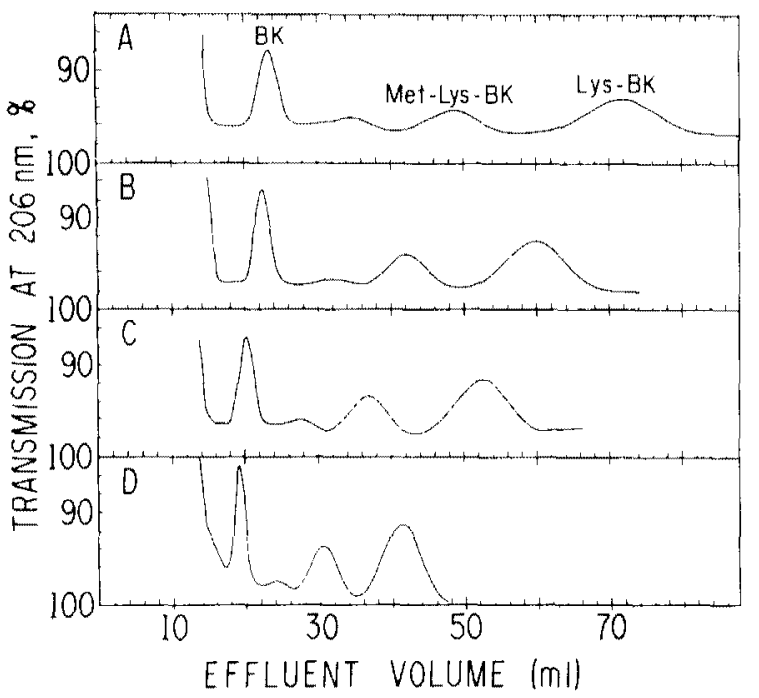

FIG. 2. Effect of sodium chloride concentration on the equilibrium chromatography of kinins. The column was operated as described in the legend to Fig. 1. The elution buffer contained $0.02 \mathrm{M}$ Tris $-\mathrm{HCl}$ buffer, $\mathrm{pH} 8.10$ and: (A) $0.11 \mathrm{M} \mathrm{NaCl}$; (B) $0.12 \mathrm{M}$ $\mathrm{NaCl}$; (C) $0.13 \mathrm{M} \mathrm{NaCl}$; and (D) $0.15 \mathrm{M} \mathrm{NaCl}$. The samples were the same as those described for Fig. 1, top. Transmission at $206 \mathrm{~nm}$ was determined with a Uvicord III using a microflow cell.

ference due to overlapping. Approximate values for $K_{\mathrm{ax}}{ }^{9}$ the distribution coefficient (14), are: bradykinin, 10; Met-Lys-bradykinin, 20; and Lys-bradykinin, 30 . The component eluted at $30 \mathrm{ml}$, detected by biological activity and absorbance at $206 \mathrm{~nm}$, was present only in the MetLys-bradykinin sample and may be a result of the oxidation of the sulfur in the methionine residue.

When elution is carried out with $0.02 \mathrm{M}$ Tris- $\mathrm{HCl}$ buffer, $\mathrm{pH} 7.70$, $0.06 \mathrm{M} \mathrm{NaCl}$, bradykinin is eluted at $36 \mathrm{ml}$ (Fig. 3, top). The $K_{\mathrm{ar}}$ is 19 , which is almost twice that obtained with the $\mathrm{pH} 8.10$ buffer. The $\mathrm{pH} 7.70$ buffer is used both as a second chromatographic parameter to identify bradykinin and to separate small amounts of potentiating peptides from bradykinin (Fig. 3, bottom) which are eluted on the ascending limb of the bradykinin peak at $\mathrm{pH} 8.10$. The recovery of synthetic bradykinin was generally $70-90 \%$ for samples of $10-100$ nmol. This buffer system is not useful for the identification of Lys-bradykinin and Met-Lys-bradykinin, because they are greatly retarded, and the peaks are too wide for useful quantitation.

${ }^{9} K_{\mathrm{av}}=V_{\mathrm{c}}-V_{\mathrm{t}} V_{\mathrm{t}}-V_{\mathrm{o}}$, where $V_{\mathrm{t}}$ is the elution volume of the peak tube minus the volume of the connecting Teflon tubing $(1.0 \mathrm{ml}) ; V_{n}$ is void volume $(1.2 \mathrm{ml})$, and $V_{\mathrm{t}}$ is the total bed volume $(3.0 \mathrm{ml})$. 


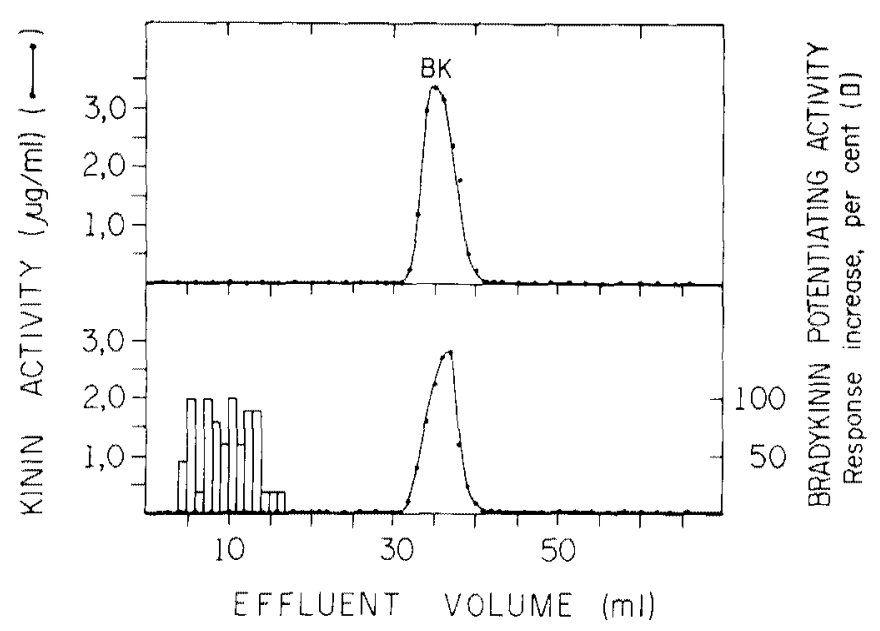

FIG. 3. Equilibrium chromatography of the synthetic bradykinin (top) and the kinin released by trypsin acting on acid-denatured human plasma (bottom) on SP-Sephadex $\mathrm{C}-25$ at $\mathrm{pH} 7.70$. The column, $0.3 \times 50 \mathrm{~cm}$, was developed with $0.02 \mathrm{M}$ Tris $-\mathrm{HCl}$ buffer, $\mathrm{pH} 7.7,0.06 \mathrm{M} \mathrm{NaCl}$ at $6 \mathrm{ml} / \mathrm{hr}, 25^{\circ} \mathrm{C}$. The samples were: (top) $20 \mu \mathrm{g}$ of bradykinin: (bottom) tryptic hydrolysate derived from $5 \mathrm{ml}$ of plasma and containing $20 \mu \mathrm{g}$ of bradykinin equivalents. Biological activity was determined with the isolated guinea pig ileum assay.

\section{Effects of Operating Conditions}

The equilibrium chromatography of these structurally related peptides is extremely sensitive to the operating conditions. Variations of \pm 0.10 $\mathrm{pH}$ unit of the buffer affect the separation of kinins 10 and 11 . The effect of some experimental conditions on the separation of the kinins at $\mathrm{pH} 8.10$ is documented below.

\section{$\mathrm{NaCl}$ Concentration}

Figure 2A-D shows that the elution position and peak width of each peptide are extremely sensitive to the $\mathrm{NaCl}$ concentration of the eluting buffer. The experiments were carried out with $0.02 \mathrm{M}$ Tris- $\mathrm{HCl}$ buffer, $\mathrm{pH}$ 8.10. The variation in $\mathrm{NaCl}$ concentration from 0.11 to $0.15 \mathrm{M}$ is reflected in the change of elution position of $\mathrm{K}-10$ from $72 \mathrm{ml} 41 \mathrm{ml}$, respectively. The effect is not as large for $\mathrm{K}-11(48-30 \mathrm{ml})$ and is small for K-9. Band broadening is observed when the retention volume is increased. In order to have a rapid analysis with acceptable baselines between $\mathrm{K}-11$ and $\mathrm{K}-10$, we use $0.12 \mathrm{M} \mathrm{NaCl}$ (Fig. 2B). However, the $0.11 \mathrm{M} \mathrm{NaCl}$ is useful for the complete separation of the contaminant present in the commercial samples of $\mathrm{K}-11$ which is eluted at $30 \mathrm{ml}$ ( $c f$. Fig. 2A). The use of buffer containing $0.15 \mathrm{M} \mathrm{NaCl}$ provides a more rapid analysis and an increase in sensitivity because there is less dilution 
of the solute, but the separation of peptides is not complete. The effect of excess salt in the sample solution is to cause K-9 to be eluted more rapidly and, sometimes, as a double peak, whereas there is usually little or no effect on the elution of K-10 and K-11.

\section{Flow Rate}

The elution diagrams shown in Fig. 1 were obtained at a flow rate of $6 \mathrm{ml} / \mathrm{hr}\left(1.4 \mathrm{ml} / \mathrm{cm}^{2} / \mathrm{min}\right)$ and required $11 \mathrm{hr}$ for a complete analysis. When the flow rate was reduced to $3 \mathrm{ml} / \mathrm{hr}$, a narrowing of the elution profiles was observed. Attempts to increase the flow rate to $12 \mathrm{ml} / \mathrm{hr}$ caused an irreversible compression of the resin.

\section{Temperature}

In order to test the effect of temperature on the chromatographic system, the column was operated at 20,25 , and $30^{\circ} \mathrm{C}$ with $\mathrm{pH} 8.10$ buffer prepared at $21^{\circ} \mathrm{C}$. The elution of the three kinins was retarded when the temperature was increased. The maximum retardation was $4.0 \mathrm{ml}$ for K-10. There was no detectable effect of temperature on the width of the elution profile for each peptide.

\section{Multiple Use of the Same Column}

The effect of repeated cycling of the column, development, regeneration with $\mathrm{NaOH}$, and re-equilibration of the resin, was tested by monitoring the elution diagram obtained after 13 complete cycles. No effect on the resolution, reproducibility, or recovery of peptides was observed.

\section{Sample Volume}

Samples are applied in $0.05 \mathrm{M}$ MOPS- $\mathrm{HCl}$ buffer, $\mathrm{pH} \mathrm{7.0,} \mathrm{con-}$ taining $15 \%$ PEG (v/v) to both the $\mathrm{pH} 8.10$ and 7.70 columns. By reducing the $\mathrm{pH}$ and ionic strength of the sample solution below that of the equilibrating buffer, $0.5-4.0 \mathrm{ml}$ samples can be applied to the $0.28 \times 50$ $\mathrm{cm}$ column which has a void volume of $1.2 \mathrm{ml}$. In separate experiments not illustrated here, elution diagrams for a mixture of the three peptides were obtained for 1-, 2-, 3-, and 4-ml samples applied with 1-, 2-, 3-, and 4-ml sample tubes. As the sample volume increased from 1 to $4 \mathrm{ml}$, the elution volume for each peptide increased $4 \mathrm{ml} / \mathrm{ml}$ of sample volume, and there was some widening of the elution envelope. We used the same sample tube, and the variations in sample volume (MOPS- $\mathrm{HCl}$ buffer containing PEG) are compensated for by the addition of MOPS$\mathrm{HCl}$ buffer without PEG. In this way, the total volume of MOPS- $\mathrm{HCl}$ buffer applied to the column is constant, though the sample volume is variable (8). The efficacy of the sample application tube and the use of 
PEG in the sample solution are indicated by the observation that a $4.0-\mathrm{ml} \mathrm{sample}$ of cysteic acid is eluted in a total volume of $4.2 \mathrm{ml}$.

\section{Recovery of Activity and Limit of Detection}

The recovery of biological activity from the SP-Sephadex column operated at $\mathrm{pH} 8.1$ was $70-90 \%$ for $10-100 \mathrm{nmol}$ of each peptide with the isolated guinea pig ileum used for assay. The smallest amount of each peptide which could be recovered from the column in yields of $50-90 \%$ was $0.5,8.0$, and 6.0 for $\mathrm{K}-9, \mathrm{~K}-10$, and $\mathrm{K}-11$, respectively. Smaller quantities of the peptides could be detected in the effluent, but could not be measured accurately. In this case, when the displacement in the baseline value of the bioassay with $0.4 \mathrm{ml}$ of effluent coincided with the correct elution position, the effluent corresponding to the peak tubes was pooled and assayed. The lower limit of detection for the complete system, i.e., column and ileum bioassay, is $0.2,4$, and $3 \mathrm{nmol}$ for bradykinin, Lys-bradykinin, and Met-Lys-bradykinin, respectively (cf. Discussion section). The large difference in the limit of detection for bradykinin, as compared to Lys-bradykinin or Met-Lys-bradykinin, is due to the lower sensitivity of ileum for the larger peptides (15) and the greater dilution of K-10 and K-11 during chromatography.

\section{Elution Positions of Other Biologically Active Peptides}

Angiotensin I and II and histamine do not interfere with the identification of bradykinin on the SP-Sephadex column at $\mathrm{pH} 7.70$, for they are eluted before bradykinin. Substance $\mathrm{P}$ and serotonin are eluted near bradykinin. These substances are distinguishable from bradykinin on the basis of enzyme inactivation and specific pharmacological inhibitors. Chromatographic systems for these vasoactive substances will be described. ${ }^{10}$

\section{Identification of Kinin Released by Trypsin Acting on Acid-Denatured Human Plasma}

Hydrolysates corresponding to 20 and $100 \%$ of the maximum releasable kinin activity were analyzed in order to determine if $\mathrm{K}-10$ and $\mathrm{K}-11$ are detectable intermediates in the production of K-9. The separation of kinin activity from salts and buffers present in ethanol extracts of plasma ${ }^{11}$

${ }^{10}$ M. L. Reis. W. Draghetta, and L. J. Greene, manuscript in preparation.

11 The AG 11A8 step could not be eliminated by diluting the ethanol extract of the trypsin hydrolysate with the SP-Sephadex sample buffer before chromatography. When the ethanol extract corresponding to $1 \mathrm{ml}$ of plasma was diluted with $2.5 \mathrm{ml}$ of MOPS buffer and was chromatographed at pH 7.70, two peaks of kinin activity which were not resolved were obtained. When synthetic bradykinin was chromatographed in the presence of $1 \mathrm{ml}$ of extract under the same conditions. the double peak of activity was also obtained. The additional peak was eluted more rapidly 
is described in Ref. (5). Eighty-eight percent of the kinin activity was recovered in a solution which had $142 \mu \mathrm{mho} / \mathrm{cm}$ of conductivity at a volume equal to that of the plasma from which it was prepared. The conductivity value is equivalent to $1.2 \mathrm{~mm} \mathrm{NaCl}$. The kinin activity represents approximately $0.06 \%$ of the weight of material in the fraction after desalting, with the remainder probably composed of peptides and proteins.

The elution diagram for the SP-Sephadex equilibrium chromatography,

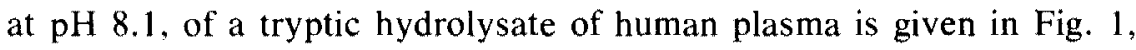
bottom. The sample contained the maximum releasable kinin activity derived from $6 \mathrm{ml}$ of plasma. All of the kinin activity was eluted in the position of bradykinin in a $70 \%$ yield. Sometimes, a small amount of bradykinin-potentiating peptides is eluted between $5 \mathrm{ml}$ and the ascending limb of the bradykinin peak. Kinin activity was not detected either before or after trypsin treatment of a pool of the effluent corresponding to $33-45 \mathrm{ml}$. This treatment would have converted $\mathrm{K}-11$, if it had been present, to K-9 with a 10 -fold increase in specific activity. Bradykinin was also the only kinin detected in a trypsin hydrolysate which had been analyzed after $20 \%$ of the total potential kinin activity had been released. In this experiment, which also indicates that K-10 and K-11 were not detectable intermediates in the early phase of the release of $\mathrm{K}-9$, the sample contained $10 \mu \mathrm{g}$ of bradykinin equivalents derived from $10 \mathrm{ml}$ of plasma. Seventy-four percent of the biological activity was recovered from the SP-Sephadex column.

Figure 3 , bottom, shows the result obtained when an aliquot of the trypsin hydrolysate, corresponding to $100 \%$ release of kinin activity, was chromatographed at $\mathrm{pH}$ 7.7. This buffer system provides a second equilibrium chromatography parameter for the identification of bradykinin and completely separates plasma bradykinin-potentiating peptides from bradykinin. The recovery of biological activity was $60 \%$ for this experiment and $55 \pm 10 \%$ for six others. The bradykinin-potentiating peptides are eluted in the effluent from 4 to $17 \mathrm{ml}$. The low recovery of activity for both columns is accounted for, in part, by the separation of plasma bradykinin-potentiating peptides from bradykinin, which would lead to an overestimation of the kinin activity in the mixture when the bioassay is used $(9,10)$. On the basis of the recovery of bradykinin from the SP-Sephadex column at $\mathrm{pH} 7.70$, we estimate that approximately $25-30 \%$ of the apparent kinin activity present in the trypsin hydrolysate of human plasma is due to the bradykinin-potentiating peptides. On this basis, human plasma contains $4.0-4.5 \mu \mathrm{g}$ of bradykinin equivalents $/ \mathrm{ml}$ of plasma rather than the $6.0 \pm 0.7 \mu \mathrm{g} / \mathrm{ml}$ obtained by bioassay of the hydrolysate. Louhija and Sipilä (16), who used IRC-50 resin to separate bradykinin from potentiating peptides and radioimmunoassay to measure directly the bradykinin in the mixture (17), showed that the potentiating peptides account for nearly $50 \%$ of the 
kinin activity and reported values of $3.36 \pm 0.49 \mu \mathrm{g}$ of bradykinin equivalents/ml of plasma. Estimates based on chromatographic recoveries are less accurate than the radioimmunoassay method.

The kinin activity released by trypsin acting on acid-denatured plasma is identified as bradykinin on the basis of its chromatographic behavior in two equilibrium chromatography systems. The identification is confirmed by experiments with carboxypeptidase $\mathrm{B}$ and $\alpha$-chymotrypsin in which the rates of inactivation were equivalent to that of synthetic bradykinin.

\section{DISCUSSION}

The objective of this study was to develop an analytical method for the identification and measurement of bradykinin and related peptides at nanomole levels in physiological solutions and enzymatic hydrolysates. Analytical procedure have been described for the separation of the three peptides by paper chromatography and paper electrophoresis (18) [cf. also Ref. (19) which indicates that reported electrophoretic separations were not reproduced], high-voltage paper electrophoresis (pyridineacetic acid buffer) (20); gel filtration on Sephadex G-15 (21), and gradient elution chromatography on CM-cellulose (22) or CM-Sephadex (23). An excellent review and analysis of the chromatographic approaches to the problem of extracting, desalting, and separating kinins is given in Ref. (24). The method for the equilibrium chromatography of kinins described here, when used with the desalting procedure in the accompanying paper (5), is more effective and convenient than these other methods for complete separation of the peptides and for unambiguous identification, measurement, and high recovery of nanomole quantities of these peptide hormones from solutions containing large amounts of buffer salts.

Equilibrium chromatography on SP-Sephadex at $\mathrm{pH} 8.10$ provides an extremely selective and reproducible method for the separation and identification of the three major kinins. A second parameter for the identification of bradykinin, which also separates the hormone from plasma bradykinin-potentiating peptides, is obtained by equilibrium chromatography at $\mathrm{pH} \mathrm{7.70.} \mathrm{The} \mathrm{chromatographic} \mathrm{behavior} \mathrm{of} \mathrm{these}$ peptides is extremely sensitive to $\mathrm{pH}$ and ionic strength and, to a lesser extent, temperature and flow rate. When the system is standardized with synthetic peptides and the operating conditions are held constant, reproducible elution diagrams are obtained with columns that can be used repeatedly. The large number of combinations of $\mathrm{pH}$ and ionic strength which are available for equilibrium chromatography of these peptides provide the versatility and selectivity needed for the extension of this method to the separation of other vasoactive cationic components. ${ }^{10}$

The identification of the kinin released by trypsin acting on acid- 
denatured human plasma is presented as an illustration of an application of the method to a complex mixture. Webster and Pierce (25) showed that bradykinin is the major kinin released from human plasma, and, subsequently, Habermann and Belennemann (22) obtained the same result with trypsin acting on purified bovine kininogen [cf. Ref. (26)]. The small amount of K-10 (2-3\%) detected by Webster and Pierce (25) in preparative experiments with $500 \mathrm{ml}$ of plasma could not have been detected in the analytical experiments reported here. The attempt to detect $\mathrm{K}-11$ as an intermediate in the early phase of the reaction $(20 \%$ of maximum release) is complicated both by the fact that $\mathrm{K}-11$ is rapidly converted to K-9 by trypsin and by the relatively slow sensitivity of the guinea pig ileum for $\mathrm{K}-11$. We estimate that, if the hydrolysate had contained $23 \% \mathrm{~K}-11$ on a molar basis $3 \%$ of the total biological activity), it would not have been detected in these experiments in which hydrolysates containing $10-15 \mu \mathrm{g}$ of bradykinin equivalents were analyzed.

The applicability of the system can be improved by increasing the sensitivity of the solute-detection system. We have used the isolated guinea pig ileum assay because of its stability and reproducibility, in spite of its relatively low sensitivity as compared to other tissue preparations or other types of detection systems. For example, the isolated rat uterus is at least 20 times more sensitive to bradykinin than is the isolated guinea pig ileum and is even more sensitive to the other peptides (15). Increased sensitivity may also be achieved by use of the laminar-flow superfusion technique (27), the sensitivity of which is near or equal to that obtained by radioimmunoassay. It should be possible to combine the selectivity of the separations obtained by equilibrium chromatography with the sensitivity achievable with radio immunoassay by monitoring the column effluent by radioimmunoassay. This would overcome a serious limitation of the radioimmunoassay method, i.e., the inability to discriminate among the individual kinins when they are present in a mixture and simultaneously be insensitive to peptide fragments of these hormones $(28,29)$.

As the sensitivity of the detection method is improved, the system will become more limited to manipulative and chromatographic losses. However, we believe that a substantial increase in sensitivity, perhaps one of several orders of magnitude, can be achieved before these losses become limiting. The inclusion of radioactivity peptides in the sample solution could have provided not only an accurate and sensitive method for the determination of manipulative and chromatographic losses, but also an internal standard for elution position. However, we have not been able to rechromatograph radioactive ${ }^{14} \mathrm{C}$ - or ${ }^{3} \mathrm{H}$-labeled samples of any one of the peptides on SP-Sephadex C-25 without obtaining two or three additional more rapidly eluting radioactive components. 
The SP-Sephadex system developed in our laboratory was used by others for the identification of Met-Lys-bradykinin as the product released by porcine pepsin acting on highly purified human plasma kininogens (30), and to identify the kinins present in human urine and monitor their production and conversion by human urinary enzymes (31).

The ability to separate and measure small quantities of kinins will facilitate biochemical studies concerning their formation and inactivation, and measurements of kinin levels in physiological fluids in a variety of physiopathological situations should contribute to an understanding of the significance of the kinin system.

\section{ACKNOWLEDGMENTS}

Research was carried out at Brookhaven National Laboratory under the auspices of U. S. ERDA. Research carried out in Ribeirăo Preto, Brazil. was supported by Grant Nos. 74/047 and 75/163 from Fundação de Amparo à Pesquisa do Estado de São Paulo (FAPESP). We wish to thank Professor Mauricio Rocha e Silva, Department of Pharmacology, Faculty of Medicine of Ribeiräo Preto, for his interest in and encouragement of this research. We are grateful to $\mathrm{Mr}$. Nicholas Alonzo, Biology Department, Brookhaven National Laboratory. for advice and assistance in the construction of the apparatus. We wish to thank Mrs. Elettra Greene for her skillful assistance in the preparation and typing of this manuscript.

\section{REFERENCES}

1. Sampaio. M. U., Reis, M. L.. Fink, E., Camargo, A. C. M., and Greene, L. J. (1975) Life Sci. 16, 796 (abstract).

2. Erdös, E. G. (ed.) (1970) Bradykinin, Kallidin and Kallikrein, Handbook of Experimental Pharmacology, Vol. 25, Springer-Verlag, New York.

3. Pisano, J. J., and Austin, K. F. (eds.) (1975) Chemistry and Biology of the Kallikrein-Kinin System in Health and Disease. Fogarty International Center Proceedings No. 27, U. S. Government Printing Office, Washington, D. C. (1976).

4. Pisano, J. J. (1975) in Proteases and Biological Control (Reich, E., Rif kin, D. B., and Shaw, E., eds.), pp. 199-222, Cold Spring Harbor Laboratory, Cold Spring Harbor, N. Y.

5. Reis, M. L., Draghetta, W., Camargo, A. C. M., and Greene, L. J., Anal Biochem. $81,358-368$.

6. Diniz, C. R., and Carvalho, I. F. (1963) Ann. N. Y. Acad. Sci. 104, 77-89.

7. Reis, M. L., Draghetta, W., and Greene, L. J., Anal. Biochem. 81, 346-357.

8. Alonzo, N., and Hirs, C. H. W. (1968) Anal. Biochem. 23, 272-288.

9. Hamberg. U. (1968) Ann. N. Y. Acad. Sci. 146, 517-526.

10. Aarsen. P. N. (1968) Brit. J. Pharmacol. Chemother. 32, 453-465.

11. Hirs, C. H. W. (1967) in Methods in Enzymology (Hirs. C. H. W., ed.), Vol. 11. pp. 325-329, Academic Press, New York.

12. Ferreira, S. H.. Bartelt, D. C., and Greene, L. J. (1970) Biochemistry 9, 2583-2593.

13. Hirs, C. H. W., Moore, S., and Stein, W. H. (1953) J. Biol. Chem. 200, 493-506.

14. Reiland, J. (1971) in Methods in Enzymology (Jakoby, W, J., ed.). Vol. 22, pp. 287-321, Academic Press. New York.

15. Reis, M. L.. Okino. L., and Rocha e Silva. M. (1971) Biochem. Pharmacol. 20, 2935-2946.

16. Louhija. A., and Sipilä, R. (1971) Acta Pharmacol. Toxicol, 30, 122-128. 
17. Sipilä, R., and Louhija. A. (1976) Biochem. Pharmacol. 25, 543-545.

18. Gapanhuk, E., and Henriques, O. B. (1968) J. Chromatogr. 32, 782-784.

19. Lalka, D., and Back, N. (1971) Biochim. Biophys. Acta 236, 47-51.

20. Camargo, A. C. M., Ramalho-Pinto, F. J.. and Greene, L. J. (1972) J. Neurochem. $19,37-49$.

21. Habal, F. M., Burrowes, C. E., and Movat, H. Z. (1976) in Kinins. Pharmacodynamics and Biological Roles (Sicuteri, F., Back, N., and Haberland, G. L.. eds.) Advan. Exp. Med. Biol. Ser., Vol, 21, pp. 23-36, Plenum Press, New York.

22. Habermann, E., and Blennemann, G. (1964) Naunyn Schmiedebergs Arch. Exp. Pathol. u. Pharmakol. 249, 357-373.

23. Miwa, 1., Erdös, E. G., and Seki. T. (1969) Proc. Soc, Exp. Biol, Med. 131, $768-772$.

24. Pierce, J. V. (1970) in Bradykinin, Kallidin and Kallikrein, Handbook of Experimental Pharmacology (Erdös, E. G., ed.). Vol. 25. pp. 21-51. Springer-Verlag, New York.

25. Webster. M. E., and Pierce. J. V. (1963) Ann. N. Y. Acad. Sci. 104, 91-107.

26. Prado, J. L. (1970) in Bradykinin, Kallidin and Kallikrein, Handbook of Experimental Pharmacology (Erdös. E. G., ed.), Vol. 25. pp. 156-192, Springer-Verlag. New York.

27. Ferreira. S. H., and De Souza Costa. F. (1976) Eur. J. Pharmacol. 39, 379-381.

28. Fischer, J., Spragg, J., Talamo, R. C.. Pierce, J. V., Suzuki, K., Austen. K. F., and Haber, E. (1969) Biochemistry 8, 3750-3757.

29. Mashford, M. L., and Roberts, M. L. (1972) in Vasopeptides: Chemistry. Pharmacology and Pathophysiology (Back, N., and Sicuteri, F., eds.) Advan. Exp. Med. Biol. Ser., Vol. 21, pp. 23-32, Plenum Press, New York.

30. Guimarães, J. A., Pierce, J. V., Hial, V., and Pisano, J. J. (1976) in Kinins. Pharmacodynamics and Biological Roles (Sicuteri, F., Back, N., and Haberland, G. L., eds.) Advan. Exp. Med. Biol. Ser., Vol. 21, pp. 265-269, Plenum Press. New York.

31. Hial, V., Keiser, H. R., and Pisano, J. J.. Biochem. Pharmacol., in press. 